\title{
A-STATISTICAL CONVERGENCE OF APPROXIMATING OPERATORS
}

\author{
O. Duman, M. K. Khan AND C. ORHAN
}

Abstract. In this paper we provide various approximation results concerning the classical Korovkin theorem via $A$-statistical convergence. We also study the rates of $A$-statistical convergence of approximating positive linear operators and give some examples.

Mathematics subject classification (2000): 41A25, 41A36; $40 \mathrm{~A} 05$. theorem.

Key words and phrases: A -statistical convergence, sequence of positive linear operators, the Korovkin

\section{REFERENCES}

[1] F. Altomare And M. Campiti, Korovkin type Approximation Theory and its Application; Walter de Gryter Publ. Berlin, 1994.

[2] R. BOJANIC AND F. CHENG, Estimates for the rate of approximation of functions of bounded variation by Hermite-Fejer polynomials, Proceedings of the conference of Canadian Math. Soc. 3 (1983), 5-17.

[3] R. BoJANIC AND M. K. KHAN, Summability of Hermite-Fejer interpolation for functions of bounded variation, J. Nat. Sci. Math. 32 No. 1 (1992), 5-10.

[4] R. A. Devore, The Approximation of Continuous Functions by Positive Linear Operators; Lecture Notes in Mathematics, Springer-Verlag, 293 (1972), Berlin.

[5] J. S. CONNOR, On strong matrix summability with respect to a modulus and statistical convergence; Canad. Math. Bull. 32 (1989), 194-198.

[6] H. FAST, Sur la convergence statistique; Colloq. Math. 2 (1951), 241-244.

[7] A. R. Freedman And J. J. SEMBer, Densities and summability; Pacific J. Math. 95 (1981), $293-305$.

[8] J. A. FRIDY, On statistitical convergence; Analysis, 5 (1985), 301-313.

[9] J. A. FrIDY, Minimal rates of summability, Canad. J. Math. 30 (1978), 808-816.

[10] J. A. Fridy, H. I. Miller AND C. ORhan, Statistical rates of convergence; Acta Sci. Math (Szeged); to appear.

[11] J. A. Fridy AND H. I. MiLler, A MATRIX CHARACTERIZATION OF STATISTICAL CONVERGENCE; Analysis, 11 (1991), 59-66.

[12] A. D. GADŽIEV, The convergence problem for a sequence of positive linear operators on unbounded sets, and theorems analogous to that of P. P. Korovkin; Soviet Math. Dokl. 15 (1974), No. 5, 1433-1436.

[13] A. D. GADJIEV AND C. ORHAN, Some approximation theorems via statistical convergence; Rocky Mountain J. Math. 32 (2002), 1-10.

[14] G. H. Hardy, Divergent Series; Oxford Univ. Press, London, 1949.

[15] M. K. Khan, B. Della Vecchia AND A. FASSIH, On the monotonicity of positive linear operators; Journal of Approximation Theory, 92 (1998), 22-37.

[16] E. KOLK, Matrix summability of statistically convergent sequences; Analysis, 13 (1993), 77-83.

[17] P. P. Korovkin, Linear Operators and Approximation Theory; India, Delhi, 1960.

18] B. KuTTNER, On the Gibbs phenomenon for Riesz means, J. London Math. Soc. 19 (1944), $153-161$.

[19] M. Marouf, Summability Matrices that Preserve Various Types of Sequential Equivalence, Ph. D. Dissertation, Department of Mathematics, Kent State University, Kent, Ohio, 1989.

[20] H. I. MilleR, Rates of convergence and topics in summability theory, Radovi Akademije Nauka $\mathrm{i}$ Umjetnosti BiH, LXXIV/22 (1983), 39-55.

[21] H. I. MiLlER, A measure theoretical subsequence characterization of statistical convergence; Trans. Amer. Math. Soc. 347 (1995), 1811-1819.

[22] O. SZASZ, Gibbs phenomenon for Hausdorff means, Trans. Amer. Math. Soc. 69 (1950), 440-456.

[23] O. SzASZ, On the Gibbs phenomenon for Euler means, Acta Scientiarum Math. 12, part b, (1950), $107-111$ 